\title{
Nutrition Class by Instagram : Interventions to Improve The Diet Quality, Physical Activity and Waist Circumfeence Among Female College Students with Obese
}

\author{
Fillah Fithra Dieny ${ }^{1,2^{*}}$; Deny Yudi Fitranti ${ }^{1,2}$; Firdananda Fikri Jauharany ${ }^{1}$; Suryawati ${ }^{1}$; A \\ Fahmy Arif Tsani ${ }^{1,2}$; Ayu Rahadiyanti ${ }^{1,2}$
}

${ }^{1}$ Department of Nutrition Science, Faculty of Medicine, Universitas Diponegoro

${ }^{2}$ Center of Nutrition Resaerch, Faculty of Medicine, Universitas Diponegoro

\section{ARTICLE INFO}

Article history:

Received October 02, 2020

Accepted December 02, 2020

Published April 15, 2020

\section{Keyword:}

Instagram

Nutrition education

Motivational interviewing

Obesity

Women of childbearing age

\begin{abstract}
A B S T R A C T
Female students are group of women childbearing age (WUS) or preconception. Obesity in WUS or the preconception period can interfere with future pregnancies and interfere with metabolism and hormones. Obese women with obesity need to change their behavior so that it needs increased knowledge and motivation as a basis for behavior change. This research objective was to determine the effect of nutrition education and motivation classes on the practice of healthy weight loss in obese women. This quasi-experimental research with pre-posttest control group design on 24 female women who met the inclusion criteria was divided into 2 groups using the simple randomization method. The independent variable is the Instagram Nutrition School program for 1 month, consisting of nutritional counseling with a motivational interviewing strategy and social mediabased nutrition education classes on Instagram, while the control group is given education through leaflet media. The dependent variable is knowledge of healthy weight loss, quality of diet and changes in anthropometric profiles, namely body weight, body mass index, waist circumference and percent body fat. Independent T-test and Mann Whitney Test were used to assess differences in knowledge scores on healthy weight loss, diet quality, and differences in anthropometric deltas. There was a significant difference in $\Delta$ knowledge score $(p=0.002), \Delta$ score of moderation $(\mathrm{p}=0.001), \Delta$ total physical activity score $(\mathrm{p}=0.002)$, and $\Delta$ moderate physical activity $(\mathrm{p}<0.001)$, mean waist circumference $(\mathrm{p}=$ $0.047)$, and $\Delta$ waist circumference $(\mathrm{p}=0.032)$ after intervention. The Instagram Nutrition School Program has been proven to increase nutritional knowledge, change eating behavior, and increase physical activity.
\end{abstract}

This open access article is under the CC-BY-SA license.

Sekolah Gizi Instagram: Intervensi untuk

Memperbaiki Kualitas Diet, Aktivitas Fisik, dan

Lingkar Pinggang pada Mahasiswa Wanita dengan Obesitas
Kata kunci:

Instagram

Edukasi gizi

Motivational interviewing

Obesitas

Wanita usia subur

*) corresponding author

Department of Nutrition Science, Faculty of

\section{A B S T R A K}

Mahasiswi merupakan kelompok Wanita Usia Subur (WUS) atau prakonsepsi. Obesitas pada WUS atau periode prakonsepsi dapat mengganggu kehamilan di masa depan dan mengganggu metabolisme dan hormonal. WUS obesitas perlu merubah perilaku sehingga dibutuhkan peningkatan pengetahuan dan motivasi sebagai dasar perubahan perilaku. Penelitian ini bertujuan untuk mengetahui pengaruh edukasi gizi dan kelas motivasi terhadap praktik healthy weight loss pada WUS obesitas. Penelitian quasi-experimental with pre-post test control group design pada 24 WUS yang memenuhi kriteria inklusi dibagi menjadi 2 kelompok dengan metode simple randomization. Variabel bebas adalah program Sekolah Gizi 
Medicine, Universitas Diponegoro, Semarang, Central Java, Indonesia

Email: fillahdieny@gmail.com

DOI: https://doi.org/10.30604/jika.v6i1.360
Instagram selama 1 bulan, terdiri dari konseling gizi dengan strategi motivational interviewing dan kelas edukasi gizi berbasis sosial media Instagram, sedangkan kelompok kontrol diberikan edukasi melalui media leaflet. Variabel terikat adalah pengetahuan healthy weight loss, kualitas diet dan perubahan profil antropometri yaitu berat badan, indeks massa tubuh, lingkar pinggang dan persen lemak tubuh. Independent T-test dan Mann Whitney Test digunkaan untuk mengkaji perbedaan skor pengetahuan healthy weight loss, kualitas diet, dan perbedaan delta antropometri. Terdapat perbedaan yang signifikan pada $\Delta$ skor pengetahuan ( $\mathrm{p}=0,002), \Delta$ skor moderasi $(\mathrm{p}=0,001), \Delta$ skor total aktifitas fisik $(p=0,002)$, dan $\Delta$ aktifitas fisik sedang $(p<0,001)$, rerata lingkar pinggang $(p=0,047)$, dan $\Delta$ lingkar pinggang $(p=0,032)$ setelah intervensi. Program Sekolah Gizi Instagram terbukti meningkatkan pengetahuan gizi, merubah perilaku makan, dan meningkatkan aktivitas fisik.

This open access article is under the CC-BY-SA license.

\section{INTRODUCTION}

Obesity is defined as an abnormal condition due to the accumulation of fat in the body which can have an impact on health problems (Hruby \& Hu, 2015). Obesity can be caused by low diet quality, such as excessive consumption of carbohydrate, sugar, fat sources but having a sedentary life style and low physical activity (Kim, 2019). Obesity can be experienced by various groups, including women of childbearing age (WUS). Women of childbearing age are married or unmarried women aged 15-49 years (F. Dieny et al., 2019). Women of childbearing age as a vulnerable group have a greater risk for obesity (Jonikas et al., 2016).

Research data shows that the prevalence of obesity in women has increased by $40 \%$ in the world (Sinaga et al., 2018). According to Baseline health research 2018 data, the prevalence of obesity in adult women aged $>18$ years is $29.3 \%$ and adult men is $14.5 \%$ (Indonesian Ministry of Health, 2018). Supported by obesity prevalence data in Central Java, which states that the obesity rate in adult women reaches 27.5\% (Indonesian Ministry of Health, 2018). This shows that the obesity rate in women tends to be higher than that of men.

Obesity in WUS, besides being able to interfere with future pregnancies, also disrupts metabolic and hormonal processes (Youngwanichsetha, 2018). This occurs when visceral fat cells alter metabolism by secreting adipokines (adiponectins and cytokines) which interfere with hormonal processes. In addition, obesity encourages changes in various hormone regulations such as insulin, androgens, and sex hormone binding globulin which results in anovulation, infertility and a higher risk of miscarriage (F. Dieny et al., 2019).

Female students are group of women of childbearing age (WUS) who are prone to obesity because they have various risky lifestyles. One of the reasons for this risky lifestyle is that most universities in Indonesia are located in big cities and are close to various places that sell fast food of various prices. This situation is a supporting factor for students to frequently consume fast food. Students who come from various regions live in boarding houses close to the campus. The all-practical lifestyle encourages many female students to choose to buy food from outside instead of processing their own food. Food purchased from outside tends to be less healthy than food prepared at home and tends to be associated with excess fat intake and lead to obesity (Townshend \& Lake, 2017).
WUS as a mother or prospective mother needs knowledge and a good lifestyle to prepare a quality generation. In obesity WUS, one way that can be taken is by making weight loss efforts with safe and appropriate treatment (Durrer Schutz et al., 2019). The treatment of obesity requires a change in the behavior of the individual itself, so that sufficient knowledge and motivation are needed as a basis for behavior change (Zeidi \& Hajiagha, 2013). Education is one of the methods and efforts to increase knowledge. An appropriate educational media is needed so that information can be conveyed effectively (Rodriguez-Cristobal et al., 2017).

In this digital era, social media is one of the media that is considered quite effective in conveying various information. Social media users can access all information quickly and easily, communicate with each other and participate (Nugraheni \& Yuni, 2017). According to the e-marketer market research institute, the population of internet users in Indonesia reached 83.7 million people in 2014 which is the sixth largest in the world (Panuju, 2017). Instagram is one of the popular social media in Indonesia, especially teenagers and early adults. Instagram is popular because of the several advantages offered by this feature which focuses on images and videos so that users can get a clearer visualization of information (Sari \& Lubis, 2017). Social media Instagram with its various advantages and the number of users reaching 130 million in 2018 can be a new alternative to convey messages and health information (Santoso et al., 2017).

Research states that knowledge alone is not sufficient for behavior change (Mirkarimi et al., 2015). It takes encouragement or motivation to apply known knowledge. Regarding weight loss efforts in obese people, several studies have stated that the mentoring program in providing counseling is quite effective in changing behavior (Christie \& Channon, 2014). Motivational Interviewing (MI) as a method of counseling has been shown to have an impact on behavior modification, including diet and physical activity (Martins \& McNeil, 2009). Instagram Nutrition School is a social mediabased nutrition education program, namely Instagram which combines counseling that focuses on providing motivation. Providing education through social media with counseling through MI is expected to be an effective combination in efforts to lose weight in obese WUS. Based on this background, this research aims to determine the effect of 
nutrition education and motivation classes on the practice of healthy weight loss in obese women.

\section{METHOD}

This research was included in the public nutrition research conducted on obesity WUS at Diponegoro University Semarang on July-August 2019. The research design used a quasi-experimental with pre-posttest control group design. This research has received permission from the Research Ethics Commission of the Medical Faculty and Dr. Kariadi Semarang No. 479 / EC / KEPK / FK UNDIP / XI / 2019.

The target population in this research were active students of Diponegoro University with a population reached by active students of Diponegoro University aged 19-25 years who had obesity nutritional status (BMI> $24.9 \mathrm{~kg} / \mathrm{m} 2$ ). The selection of subjects used the consecutive sampling method. The inclusion criteria in this research were the subject of an active student at Diponegoro University; obesity nutritional status (BMI> $24.9 \mathrm{~kg} / \mathrm{m} 2$ ); 19-23 years old; single; not following a diet program or weight loss program from another party; have a level of knowledge and motivation regarding the healthy weight loss category is less; active as an Instagram user, with the criteria being active every day to open Instagram; and willing to take part in the research by filling out an informed consent form. The exclusion criteria in this research were resigning to be the research subject. Based on the inclusion and exclusion criteria, the total sample size was 30 people and divided into 2 groups using the simple randomization method, namely the treatment $(\mathrm{P})$ and control $(\mathrm{K})$ groups. A total of six samples dropped out because the data obtained were incomplete, so the total sample used in this research was 24 people divided into two groups, namely 14 treatment groups $(\mathrm{P})$ and 10 control groups (K).

Initial screening was carried out according to the inclusion criteria for subject selection including anthropometric measurements, namely body weight, height, body fat percent, waist circumference, hip circumference, and general data interview subjects. Subjects who met the inclusion criteria were asked to become research subjects by filling out the informed consent. Subjects were randomly divided into 2 groups, namely the treatment group and the control group.

Prior to the intervention, each group was given nutritional information regarding the description of obesity and how to determine it, physical activity, and diet. Education was given with leaflet media once at the beginning of the meeting for \pm 30 minutes by the research team. After the fourth week of intervention, measurements of body weight, percent body fat, waist level, hip circumference were measured in the treatment and control groups.

The independent variable in this research was the provision of the Instagram Nutrition School program for one month which consisted of nutritional counseling with a motivational interviewing strategy and social media-based nutrition education classes on Instagram, while the control group $(\mathrm{K})$ was only given education through leaflet media. The nutrition education class was conducted based on social media Instagram for 30 days with the One Day One Topic system and was carried out in a closed manner, namely only the treatment group could receive education. The nutrition education provided in the form of illustrated nutritional information is complemented by simple and interesting explanations that can be read every day by the subject. In addition, subjects can ask questions / communicate directly with researchers in the comments column. Educational materials in the form of understanding obesity, how to measure obesity, recommended dietary intake for obesity, healthy diet tips and tricks, sports recommendations and other physical activities. Meanwhile, motivational interviewing was given four times a month with face-to-face meetings once a week for a duration of 15-45 minutes and was carried out individually, namely one subject by a counselor who remained until the end of the research (Mirkarimi et al., 2015).

While the dependent variable is knowledge of healthy weight loss, quality of diet and changes in anthropometric profiles, namely body weight, Body Mass Index, Waist Circumference and Percent Body Fat. Changes in knowledge were seen using a pre-test and post-test questionnaire in the form of questions about healthy weight loss totaling 20 questions. Healthy weight loss knowledge scores were categorized into good knowledge (76-100\%), sufficient knowledge (56-75\%), and poor knowledge $(<55 \%)$.

The data is processed and analyzed using statistical programs. Univariate analysis was carried out to describe the variables studied including the characteristics of the subject and a description of knowledge and diet quality in the subject before the intervention. The normality of the data was tested by Saphiro Wilk. Differences in knowledge scores changes in healthy weight loss, diet quality, and differences in anthropometric deltas in the two groups were analyzed using the independent T-test and the Mann Whitney Test.

\section{RESULTS AND DISCUSSION}

\section{Characteristics Of Research Subjects}

Table 1 illustrates that the characteristics of the subjects mostly came from the Science and Technology department, (66.7\%) and resided in Boarding Schools (58.3\%) with an allowance per month $<800,000$ rupiah $(37.5 \%)$. All subjects in this research also had a low level of nutritional knowledge, and the quality of the diet was still low. Most of the physical activity of the subject was classified as moderate physical activity, which amounted to $41.7 \%$.

Table 1

The Characteristics of Research Subject

\begin{tabular}{llcc}
\hline \multirow{2}{*}{ Characteristics } & \multicolumn{2}{c}{ Total } \\
\cline { 3 - 4 } & & $\mathbf{n}$ & $\%$ \\
\hline Major & SciTec & 16 & 66,7 \\
\multirow{2}{*}{ Stay } & Sochum & 8 & 33,3 \\
& Boarding house & 14 & 58,3 \\
& With family & 10 & 41,7
\end{tabular}




$\begin{array}{llcc}\text { Money Pocket } & >1.200 .000 & 7 & 29,1 \\ & 800.000-1.200 .000 & 8 & 33,3 \\ \text { Diet Score Quality } & <800.000 & 9 & 37,5 \\ & \text { High }(>60) & 0 & 0 \\ \text { Physical Activity } & \text { Law }((\leq 60) & 24 & 100 \\ & \text { High } & 6 & 25 \\ & \text { Moderate } & 10 & 41,7 \\ & \text { Law } & 8 & 33,3\end{array}$

Data regarding body weight, BMI, waist circumference, and percent fat were not significant differences between the two P1 and control groups, which means that the characteristics of the subjects before the intervention were the same. Anthropometric profile data is shown in table 2 as follows.

Tabel 1

The Profil of Anthropometric Subject Before Intervention

\begin{tabular}{llll}
\hline \multicolumn{1}{c}{ Variables } & \multicolumn{1}{c}{ P1 } & & A \\
\cline { 2 - 3 } & \multicolumn{1}{c}{ Average \pm SD } & \multicolumn{1}{c}{ Average \pm SD } & \\
\hline Body Weight $(\mathrm{kg})$ & $69,8 \pm 9,9$ & $67,1 \pm 9,6$ & $0,514 \mathrm{a}$ \\
Body Mass Index $\left(\mathrm{kg} / \mathrm{m}^{2}\right)$ & $29,5 \pm 3,2$ & $28,3 \pm 2,9$ & $0,279 \mathrm{~b}$ \\
Waist Circumference $(\mathrm{cm})$ & $90 \pm 8,0$ & $85,85 \pm 10,6$ & $0,168 \mathrm{~b}$ \\
Percent Fat $(\%)$ & $34,9 \pm 4,5$ & $33,4 \pm 3,6$ & $0,292 \mathrm{~b}$ \\
\hline Note : a Independent T-Test & $\mathrm{b}=$ Mann Whitney & &
\end{tabular}

The differences changes in knowledge scores, diet quality, diet quality components, motivation and physical activity in all subjects after attending the Instagram nutrition school

Based on the analysis of the results of table 3 , a significant difference is shown in the variables $\Delta$ Knowledge
Score, $\Delta$ moderation score, $\Delta$ total score of physical activity, and $\Delta$ physical activity in the moderate category after the intervention. This shows that after the intervention there is an increase in knowledge, the components of the quality of the moderated diet and physical activity are getting better in the subject.

Table 3

The Difference Change in Average of Knowledge scores, Diet Quality, Diet Quality Components, Motivation and the amount of Physical Activity after the intervention

\begin{tabular}{|c|c|c|c|}
\hline \multirow[t]{2}{*}{ Variables } & P1 & $\mathrm{K}$ & $p$ \\
\hline & Average \pm SD & Average \pm SD & \\
\hline Knowledge (score) & $17,8 \pm 16,7$ & $-2,5 \pm 8,8$ & $0,002^{b}$ \\
\hline Motivation of healthy life style (score) & $3,64 \pm 6,73$ & $0,5 \pm 2,9$ & $0,182^{\mathrm{a}}$ \\
\hline Diet Quality (score) & $-0,64 \pm 6,7$ & $-4,2 \pm 9,6$ & $0,298^{a}$ \\
\hline Variate (score) & $8,14 \pm 2,85$ & $7,8 \pm 3,2$ & $0,952^{\mathrm{b}}$ \\
\hline Adequacy (score) & $-2,14 \pm 2,0$ & $0,4 \pm 5,25$ & $0,174^{\mathrm{a}}$ \\
\hline Moderation (score) & $1,2 \pm 4,6$ & $-6,0 \pm 5,09$ & $0,001^{\mathrm{a}}$ \\
\hline Overall Balance (score) & $0,4 \pm 1,3$ & $-0,4 \pm 1,26$ & $0,187^{\mathrm{b}}$ \\
\hline Total Physical Activity (MET score) & $1231,3 \pm 1237,5$ & $-1416,8 \pm 2067,2$ & $0,002^{b}$ \\
\hline Weight $(\mathrm{kg})$ & $-0,37 \pm 1,1$ & $0,0 \pm 1,1$ & $0,364^{\mathrm{b}}$ \\
\hline Body mass index $\left(\mathrm{kg} / \mathrm{m}^{2}\right)$ & $-0,07 \pm 0,5$ & $-0,1 \pm 0,5$ & $0,482^{\mathrm{b}}$ \\
\hline Waist size $(\mathrm{cm})$ & $-1,9 \pm 3,4$ & $1,2 \pm 3,4$ & $0,032^{b}$ \\
\hline Percent Body Fat (\%) & $-1,1 \pm 3,3$ & $-0,9 \pm 3,6$ & $0,493^{\mathrm{a}}$ \\
\hline
\end{tabular}

Table 4 shows that of all changes in anthropometric values, it is known that in the treatment group there was a decrease in body weight, body mass index and body fat percent greater than the control group but not significantly different $(\mathrm{p}<0.05)$. However, based on changes in waist circumference, there was a significant difference in anthropometric delta at $\Delta$ Waist circumference with a $\mathrm{p}$ value of 0.032 and a mean of $-1.9 \mathrm{~cm} \pm 3.4$. There is an effect of the provision of instagram-based nutrition school interventions on reducing the subject's waist circumference.

This research discusses the effect of providing nutrition education through social media Instagram and motivational interviewing on healthy weight loss in obese women. The general characteristics of knowledge of healthy weight loss, quality of diet, and motivation of healthy diet of subjects in this research were still low. Anthropometric profiles (body weight, body mass index, waist circumference percent fat) of subjects in the treatment and control groups before the intervention had no significant difference with $\mathrm{p}$ value $>0.05$. This shows that the anthropometric profiles of the two groups are in the same condition at the time of the research.

The intervention given in this research was a nutrition school for prospective manten, which is an intervention program consisting of nutrition education through Instagram to increase nutritional knowledge and assistance with motivational classes to lose weight by changing dietary lifestyle and physical activity. Instagram was chosen as a media for nutrition education because of the several advantages it offers and is considered effective in increasing the knowledge of healthy weight loss in obese women in the 
current digital era. Instagram media can be used as a platform to promote nutritional behavior as an expression of personality, interaction with other people and can reach many users including female students who are regular Instagram users. The use of Instagram can have a positive impact on health literacy because each post can be used to introduce good eating behavior and encourage reflection on food composition, although this does not necessarily lead to changes in diet (Riesmeyer et al., 2019).

Instagram as a media for delivering information has several advantages including the information submitted can be presented more fully, can be accepted at any time, information is not only in text but in visual form so that it is more interesting and easy to understand, and allows the subject to retrieve the information that has been conveyed and ask if there is information that is not clear. This statement is supported by previous research which shows that the results of increasing nutritional knowledge scores are higher in the internet-based education treatment group than in the control group (Putu et al., 2014). After the intervention, the results of this research showed that the treatment group experienced a significant increase in knowledge related to healthy weight loss compared to the control group. This means that the instagram-based intervention and motivational interviewing given to the treatment group are very effective in improving one's cognitive compared to leaflet media alone. These results reinforce the reason that the combination of media and methods of delivering information provides more effective results in conveying information so as to increase knowledge (Barnes et al., 2018).

The diet quality score in the majority of subjects before the intervention showed low results. Diet quality includes four main components, namely variety, adequacy, moderation and overall balance of the diet (Retnaningrum \& Dieny, 2015). The low quality of the diet in this research was indicated by the intake of saturated fat in the moderation component of more than the need, the variety of food groups that was low in the variation component, the lack of intake of most of the nutrients in the adequacy component and the low overall balance component. Low diet quality is associated with the consumption of foods high in energy and fat, and low in fiber and micronutrients (Kałucka et al., 2019). Based on a research on young women in Munich, it was found that media literacy and health do not automatically lead to healthier eating habits because apart from knowledge of healthy nutrition and media functions, young women act against nutritional knowledge and let their eating habits be influenced (Riesmeyer et al. al., 2019).

The quality of diet, especially in the moderation component of the subjects in this research, experienced significant differences before and after the intervention. The treatment group showed an improvement in energy intake, carbohydrates, staple food intake, total fat, saturated fat and sodium. The moderation component evaluates the intake of foods and nutrients associated with chronic disease and needs to be limited to total fat, saturated fat, cholesterol, sodium, and foods low in nutrients. A high moderation score reflects total fat as well as excess saturated fat. The improvement in the moderation component of diet quality in the treatment group in this research could be due to the increasing knowledge of the subject accompanied by a motivational boost obtained through motivational interviewing, while the control group only received education without assistance. Previous research supports that nutritional counseling, in this case the provision of motivational interviewing, has an important role in diet compliance. Motivational interviewing can establish a personal approach that can help individuals gain a better understanding of the nutritional problems faced and help make decisions in overcoming these nutritional problems (Shofia \& Sulchan, 2015). Subjects in this research were motivated to make behavioral improvements, especially focusing on reducing energy, carbohydrate and fat intake. These results are consistent with research on the impact of computer-based counseling and education which shows a decrease in fat intake in the intervention group (Ajie \& Chapman-Novakofski, 2014). Diet regulation in obese sufferers is important for weight loss programs. Several research results on healthy eating index in obese adolescents and adults, state that variation and adequacy in diet quality has a good effect on the metabolic profile of obese women (Camhi et al., 2015; F. F. Dieny et al., 2015).

After the intervention, there was a significant difference in the mean physical activity of MET and moderate physical activity in the two groups P1 and K. This shows that the physical activity of the subjects in the treatment group increased. Increasing physical activity is one of the supporting factors for achieving a healthy weight loss. In line with the results of this research, which shows that the anthropometric profile of waist circumference in the treatment group has decreased, even though there has been no weight loss. The mean difference in waist circumference anthropometric delta after intervention in the treatment group was $-1.9 \pm 3.4 \mathrm{~cm}$ compared to the control group whose mean increase was $1.2 \pm 3.4 \mathrm{~cm}$. This means that the reduction in waist circumference that occurred in the treatment group was greater than the control group. The decrease in waist circumference experienced by subjects in the treatment group could be due to the increasing motivation of the subjects in carrying out physical activities and improving their dietary patterns. In line with previous research which states that moderate intensity physical activity with a duration of 120-240 minutes per week for 6 months can significantly reduce BMI and waist circumference in the treatment group (Hamasaki, 2017). Increased physical activity as a form of energy expenditure accompanied by proper dietary regulation as a form of energy intake can be an effective alternative to obesity therapy (Ravi \& Sangeeta, 2014). The body weight of the subjects after the intervention in this research has not shown any significant changes. This is possible because the duration of intervention and monitoring in this research was only carried out for 1 month, so dietary behavior and physical activity could not be monitored afterwards. Weight loss can be achieved through a good diet and physical activity that is carried out in a sustainable manner. However, the results of this research indicate that the intervention through Instagram education and the education classes provided are proven to be effective in increasing nutritional knowledge and the practice of healthy weight loss in obese women.

\section{CONCLUSION}

Instagram Nutrition School is an effective in increasing knowledge of healthy weight loss, quality of diet, total physical activity and reducing waist circumference.

\section{Acknowledgment}

Thank you to all the research subjects, UNDIP students, and Diponegoro University through the Institute for Research and Community Service who have funded this 
research with the

Development and Implementation Research Grant 2019

\section{Declaration of Conflicting Interests}

The authors declared that no potential conflicts of interests with respect to the authorship and publication of this article.

\section{REFERENCES}

Ajie, W. N., \& Chapman-Novakofski, K. M. (2014). Impact of Computer-Mediated, Obesity-Related Nutrition Education Interventions for Adolescents: A Systematic Review. Journal of Adolescent Health, 54(6), 631-645. https://doi.org/10.1016/j.jadohealth.2013.12.019

Barnes, R. D., Ivezaj, V., Martino, S., Pittman, B. P., Paris, M., \& Grilo, C. M. (2018). Examining motivational interviewing plus nutrition psychoeducation for weight loss in primary care. Journal of Psychosomatic Research, 104, 101-107. https://doi.org/10.1016/j.jpsychores.2017.11.013

Camhi, S. M., Whitney Evans, E., Hayman, L. L., Lichtenstein, A. H., \& Must, A. (2015). Healthy eating index and metabolically healthy obesity in U.S. adolescents and adults. Preventive Medicine, 77 ,

https://doi.org/10.1016/j.ypmed.2015.04.023

23-27.

Christie, D., \& Channon, S. (2014). The potential for motivational interviewing to improve outcomes in the management of diabetes and obesity in paediatric and adult populations: A clinical review. Diabetes, Obesity \& Metabolism, 16(5), 381387. https://doi.org/10.1111/dom.12195

Dieny, F. F., Widyastuti, N., \& Fitranti, D. Y. (2015). Sindrom metabolik pada remaja obes: Prevalensi dan hubungannya dengan kualitas diet. Jurnal Gizi Klinik Indonesia, 12(1), 111. https://doi.org/10.22146/ijcn.22830

Dieny, F., Rahadiyanti, A., \& Kurniawati, D. M. (2019). Gizi prakonsepsi. Bumi Medika.

Durrer Schutz, D., Busetto, L., Dicker, D., Farpour-Lambert, N., Pryke, R., Toplak, H., Widmer, D., Yumuk, V., \& Schutz, Y. (2019). European Practical and Patient-Centred Guidelines for Adult Obesity Management in Primary Care. Obesity Facts, 12(1), 40-66. https://doi.org/10.1159/000496183

Hamasaki, H. (2017). Physical Activity and Obesity in Adults. Adiposity - Epidemiology and Treatment Modalities. https://doi.org/10.5772/64672

Hruby, A., \& Hu, F. B. (2015). The Epidemiology of Obesity: A Big Picture. PharmacoEconomics, 33(7), 673-689. https://doi.org/10.1007/s40273-014-0243-X

Jonikas, J. A., Cook, J. A., Razzano, L. A., Steigman, P. J., Hamilton, M. M., Swarbrick, M. A., \& Santos, A. (2016). Associations Between Gender and Obesity Among Adults with Mental Illnesses in a Community Health Screening Study. Community Mental Health Journal, 52(4), 406-415. https://doi.org/10.1007/s10597-015-9965-2

Kałucka, S., Kaleta, D., \& Makowiec-Dabrowska, T. (2019). Prevalence of Dietary Behavior and Determinants of Quality of Diet among Beneficiaries of Government Welfare Assistance in Poland. International Journal of Environmental Research and Public Health, 16(3). https://doi.org/10.3390/ijerph16030501
Kementerian Kesehatan RI. (2018). Riset Kesehatan Dasar 2018 (RISKESDAS 2018). Kementerian Kesehatan Republik Indonesia.

Kim, D. (2019). Factors Affecting Obesity and Waist Circumference Among US Adults. Preventing Chronic Disease, 16. https://doi.org/10.5888/pcd16.180220

Martins, R. K., \& McNeil, D. W. (2009). Review of Motivational Interviewing in promoting health behaviors. Clinical Psychology Review, 29(4), 283-293. https://doi.org/10.1016/j.cpr.2009.02.001

Mirkarimi, K., Mostafavi, F., Eshghinia, S., Vakili, M. A., OzouniDavaji, R. B., \& Aryaie, M. (2015). Effect of Motivational Interviewing on a Weight Loss Program Based on the Protection Motivation Theory. Iranian Red Crescent Medical $\begin{array}{lll}\text { Journal, } & 17(6), & \text { e23492. }\end{array}$ https://doi.org/10.5812/ircmj.23492v2

Nugraheni, Y. N., \& Yuni, A. (2017). Social Media Habit Remaja Surabaya. KOMUNIKATIF, 6(1), 13-30. https://doi.org/10.33508/jk.v6i1.1585

Panuju, R. (2017). Perilaku Mengakses Internet di Warung Kopi. $\begin{array}{lll}\text { Jurnal Sosioteknologi, } & 16(3), & 259-273 .\end{array}$ https://doi.org/10.5614/sostek.itbj.2017.16.3.3

Putu, F. Y., I Ketut, A., \& I Nyoman Gede, S. (2014). Efektifitas Penggunaan Media Cetak dan Media Elektronika Dalam Promosi Kesehatan Terhadap Peningkatan pengetahuan dan Perubahan Sikap Siswa SD. JKL (Jurnal Kesehatan Lingkungan), 4(1), 29-39.

Ravi, S., \& Sangeeta, G. (2014). Response of Paschimottanasana and Kapalabhati on Anthropometric in Obese Individuals as Per Prakriti. International Journal of Research in Ayurveda and Pharmacy, 5(3), 256-260.

Retnaningrum, G., \& Dieny, F. F. (2015). Kualitas Diet dan Aktivitas Fisik pada Remaja Obesitas dan Non Obesitas. Journal of Nutrition College, 4(4), 469-479. https://doi.org/10.14710/jnc.v4i4.10150

Riesmeyer, C., Hauswald, J., \& Mergen, M. (2019). (Un)Healthy Behavior? The Relationship between Media Literacy, Nutritional Behavior, and Self-Representation on Instagram. Media and Communication, 7(2), 160-168. https://doi.org/10.17645/mac.v7i2.1871

Rodriguez-Cristobal, J. J., Alonso-Villaverde, C., Panisello, J. M., Travé-Mercade, P., Rodriguez-Cortés, F., Marsal, J. R., \& Peña, E. (2017). Effectiveness of a motivational intervention on overweight/obese patients in the primary healthcare: A cluster randomized trial. BMC Family Practice, 18(1), 74. https://doi.org/10.1186/s12875-017-0644-y

Santoso, A. P., Baihaqi, I., \& Persada, S. F. (2017). Pengaruh Konten Post Instagram terhadap Online Engagement: Studi Kasus pada Lima Merek Pakaian Wanita. Jurnal Teknik ITS, 6(1). https://doi.org/10.12962/j23373539.v6i1.21822

Sari, M. P., \& Lubis, E. E. (2017). Fenomena Penggunaan Media Sosial Instagram sebagai Komunikasi Pembelajaran Agama Islam oleh Mahasiswa FISIP Universitas Riau. Jurnal Online Mahasiswa (JOM) Bidang Ilmu Sosial Dan Ilmu Politik, 4(2), $1-13$.

Shofia, N., \& Sulchan, M. (2015). Pengaruh Konseling Modifikasi Gaya Hidup terhadap Asupan Serat, Kadar Glukosa Darah Puasa, dan Kadar Interleukin 18 (IL-18) pada Remaja 
Obesitas dengan Sindrom Metabolik. Journal of Nutrition College, $\quad 4(3), \quad 243-251$ https://doi.org/10.14710/jnc.v4i3.10089

Sinaga, M., Worku, M., Yemane, T., Tegene, E., Wakayo, T., Girma, T., Lindstrom, D., \& Belachew, T. (2018). Optimal cut-off for obesity and markers of metabolic syndrome for Ethiopian adults. Nutrition Journal, 17(1), 109. https://doi.org/10.1186/s12937-018-0416-0

Townshend, T., \& Lake, A. (2017). Obesogenic environments: Current evidence of the built and food environments. Perspectives in Public Health, 137(1), 38-44. https://doi.org/10.1177/1757913916679860

Youngwanichsetha, S. (2018). Overweight, Obesity and Women Health. Journal of Nutrition \& Food Sciences, 08(04). https://doi.org/10.4172/2155-9600.1000e146

Zeidi, I. M., \& Hajiagha, A. P. (2013). Effect of Motivational Interviewing on Eating Habits and Weight Losing among Obese and Overweight Women. Journal of Obesity \& Weight Loss Therapy, 3(3), 1-4. https://doi.org/10.4172/21657904.1000172 